\title{
ANÁLISE DE CUPONS DE CORROSÃO SUBMETIDOS AO ENSAIO DE MONITORAMENTO
}

\author{
SILVEIRA, G.B., PEREIRA, E.C., PEREIRA, A.G.. \\ Laboratório de Materiais Avançados - LAMAV, Universidade Estadual do Norte Fluminense \\ Darcy Ribeiro - UENF, Av. Alberto Lamego, 2000, Campos dos Goytacazes - RJ, Brasil.
}

Cupons de corrosão são corpos de prova metálicos utilizados em ensaios de monitoramento de processos corrosivos, com diversos tipos e formas, entretanto, os mais empregados são de aço carbono e possuem os formatos retangulares e em disco. Entre as diversas técnicas de monitoramento da corrosão empregadas pela indústria de óleo e gás inclui a de cupons de corrosão. O conhecimento de como o desempenho dos cupons varia quando submetidos a variações das condições de exposição e das características dos próprios cupons é fundamental para que se interpretem corretamente os resultados produzidos por eles. Dentre as formas de corrosão existentes no aço, as mais comuns são do tipo alveolar e por pites. Esta última é uma forma muito localizada de ataque por corrosão, que consiste na formação de cavidades onde pequenos pites se formam. Esse é um tipo extremamente traiçoeiro, que como consequência fica sem ser detectado e que apresenta uma perda de material muito pequena até que ocorra a falha. $\mathrm{O}$ atual trabalho tem como objetivo principal avaliar o comportamento de cupons de corrosão de duas geometrias distintas, retangular e disco, bem como as formas de corrosão produzidas pelo ensaio. Os cupons foram ensaiados em loop de corrosão, tendo como fluido água potável aerada. As seguintes análises foram realizadas: análise química quantitativa para caracterização da liga metálica, exame metalográfico para verificação da microestrutura dos cupons, microscopia eletrônica de varredura com microanálise para identificação das inclusões e análise da corrosão por pites, onde as normas NACE RP 0775, ASTM G46-94 e NBR 9771 foram adotadas. O aço carbono embora tenha baixa resistência à corrosão na maioria dos meios de exposição, é o material mais utilizado na maioria das aplicações, especialmente naquelas que envolvem equipamentos e estruturas, devido à excelente resistência mecânica. Quando imerso em águas naturais, o aço carbono pode sofrer vários tipos de corrosão, dentre eles, corrosão generalizada, corrosão em frestas, corrosão por pite, além de corrosão associada a fatores mecânicos. O caso em estudo refere-se à ocorrência de corrosão localizada do tipo pites em cupons de aço carbono utilizados no programa de monitoramento da corrosão interna de dutos de transportes de petróleo e derivados. Este fato gerou uma grande preocupação, pois a ocorrência de pites pode significar que o duto está sofrendo corrosão localizada e, portanto, ações mitigadoras devem ser tomadas, para evitar vazamentos. Neste estudo, foi feita uma investigação detalhada para determinar as causas do aparecimento de pites. Os resultados mostraram que os cupons que diferem por sua geometria são processados de maneiras distintas, o que resulta em diferentes microestruturas, mesmo em cupons de mesma procedência. Com relação à análise química ambos se enquadram como aço carbono ABNT 1010.

Após ensaio em loop de corrosão foi observado que praticamente todos os cupons ensaiados apresentavam pites de corrosão, entretanto não foi estabelecida uma relação direta entre o aspecto morfológico e a ocorrência de pites. Com os resultados de microanálise foi identificado inclusões de óxidos e sulfetos de ferro e manganês. De acordo com a literatura, as inclusões são um dos fatores principais para propiciar o aparecimento de pites no aço. Ao redor destas inclusões, que são catódicas em relação à matriz, formam áreas anódicas, capazes de desprender ou arrancar estas inclusões. Por microscopia foi observado que os cupons de geometria disco apresentavam mais inclusões quando comparados à geometria retangular, fato relacionado ao maior desenvolvimento de pites mais profundos nestes cupons. 
Os resultados obtidos neste estudo indicaram que a ocorrência de pites nos cupons está relacionada com a existência de inclusões de óxidos e sulfetos de Fe e Mn. Quando os cupons são instalados nos dutos, estas inclusões ficam perpendiculares à direção do fluxo. Em contato com o líquido, o entorno dessas inclusões sofrem dissolução eletroquímica, resultando no desprendimento destas inclusões com consequente geração de pites ou pequenas frestas. Os ensaios de imersão e ensaios eletroquímicos reforçaram esta hipótese.

Palavras Chave: corrosão, cupons, monitoramento.

Financiamento: PETROBRÁS, UENF, CAPES.

\section{REFERÊNCIAS}

ABNT NBR 9771, 1987, Exame e avaliação da corrosão por pite;

ASTM G46, 1994 (reaprovada em 2005), Examination and evaluation of pitting corrosion;

GENTIL, V. Corrosão. 4ª Ed., Editora: LTC, 2003.

JAMBO, H.C.M.; FÓFANO, S. Corrosão, Fundamentos, Monitoração e Controle. Rio de Janeiro: Editora Ciência Moderna Ltda., 2008.

NACE RP0775-2005, Preparation, installation, analysis, and interpretation of corrosion coupons in oilfield operations;

TELLES, P.C.S. Materiais para Equipamentos de Processo. $6^{\text {a }}$ Ed., Rio de Janeiro. Editora: Interciência, 2003. 